IDEA - Studia nad strukturą i rozwojem pojęć filozoficznych $\mathrm{XXVIII/2}$

\title{
TOMASZ OLCHANOWSKI
}

(Białystok)

\section{PONOWOCZESNY WSPANIAEY ŚWIAT}

Rzeczywistość psychiczna jest jedyną rzeczywistością, jaką możemy doświadczyć bezpośrednio. Doświadczamy jej samotnie, żyjąc w swym subiektywnym świecie, czasem lękając się, czy nasze doświadczenie jest realne, najczęściej zaś uciekając od tego typu wątpliwości, by nie podważyć własnego zdrowia psychicznego. Poszukując tego, co wspólne w przeżyciach własnych i swych bliźnich, nadajemy tym wspólnym doświadczeniom pozory realności. Zatem opieramy poczucie bezpieczeństwa na grząskim gruncie złudzeń, ale przynajmniej grunt ten, choć wciąż jest niebezpieczny, próbowali oswoić nasi przodkowie, narzucając swoim potomkom taką a nie inną wizję świata, ludzkości, własnego plemienia, człowieka, jego przeznaczenia i natury. Obecnie jednak musimy się zmierzyć z czymś, co jeszcze do niedawna nie istniało, tak charakterystycznym dla ponowoczesności światem stojącym poza jawą a snem. Chodzi o to, że rzeczywistość coraz bardziej próbują zastąpić obrazy cieni, przesuwające się po większych i mniejszych ekranach. Nie są to ani twory realne, ani też wytwory naszej żywej wyobraźni. W tej cyfrowej rzeczywistości powołanej do istnienia przez ponowoczesnych, entuzjastycznych „uczniów czarnoksiężnika” zacierają się granice między realnym a wirtualnym, między rzeczywistością a ideologicznym fantazmatem, między światem a widmem świata. Dla istoty ludzkiej opętanej przez pragnienie stałego monitorowania, podglądania, komunikowania się, 
dzielenia się $\mathrm{z}$ anonimowymi internautami wszystkim, co widzi, wie, a nawet przeżywa i czuje, włączając $\mathrm{w}$ to najintymniejsze szczegóły dotyczące własnego ciała i stanu zdrowia, czyż nie będzie podejrzane, wręcz uznane za patologiczne, niemal każde ekstatyczne odczucie piękna natury, głębokie doświadczenie lektury, twórcze olśnienie, czy przeżycie mistyczne? W opartej na „najświętszej” ekonomii monokulturze „przejrzystości” całkiem możliwe, że tajemnica i prywatność stają się atrybutami hipokryzji i samolubstwa, zaś głębia mądrości znika pod ilością „skonsumowanych” informacji. Droga do racjonalności okazuje się być, ukrywanym za ekonomiczno-naukowymi komunałami, irracjonalnym szaleństwem napędzanym przez Tanatosa.

Zauważmy, że w „Antygonie” Sofoklesa, jak i wcześniej w tragediach Ajschylosa, pojawia się przeświadczenie (tak charakterystyczne dla religii i systemów filozoficznych wywodzących się z Półwyspu Indyjskiego), że świat jawy wcale nie jest bardziej realny niż świat snu: „O śmiertelnych pokolenia/ Życie wasze to cień cienia/ Bo któryż człowiek więcej tu szczęścia zażyje/ Nad to, co w sennych rojeniach uwije/ Aby potem z biegiem zdarzeń/ Po snu chwili runąć z marzeń"

Jeśli zatem ktoś pragnie stać się „wolnym duchem”, osiągnąć stan maksymalnej obiektywizacji, w którym to granice pomiędzy obiektywnym a subiektywnym przestają mieć większe znaczenie, powinien dojrzeć do podwójnego przebudzenia: ze świata marzeń sennych oraz świata, który uważamy za jawę, a który bywa nieraz mniej rzeczywistym niż świat marzeń sennych, ponieważ zamykamy go w swoich poglądach opartych na iluzorycznych podstawach, które bierzemy za solidne fundamenty. Zazwyczaj w naszym indywidualnym doświadczeniu racjonalna myśl kapituluje przed stanem emocjonalnym, zaś stan emocjonalny przed myślą już niekoniecznie. Tłumacze dzieł pisanych w sanskrycie czy w języku chińskim, stoją przed dylematem, ponieważ w tych językach słowo oznaczające 'umysł', 'myślenie intelektualne' oznacza również i serce (także w znaczeniu somatycznego organu). Dlatego też dobrą intuicję mają ci, którzy oddają chińskie xin jako serco-umysł. W filozofii Wschodu (najwyraźniej

\footnotetext{
1 Sofokles, Antygona, [w:] Ajschylos, Sofokles, Eurypides. Antologia tragedii greckiej, przeł. S. Srebrny, K. Morawski, J. Łanowski, Wydawnictwo Literackie, Kraków 1989, s. 290.
} 
w buddyzmie chan, znanym bardziej jako zen, który to powstał wskutek syntezy taoizmu i buddyzmu) jest czymś oczywistym, że myślenie intelektualne oraz świat emocji i uczuć są dwiema stronami tego samego procesu. W filozofii, która wykształciła się w obrębie cywilizacji zachodnioeuropejskiej, tak łudzącej się, że jest kontynuatorką filozofii Starożytnej Grecji, myśl stoi często w opozycji do sfery emocjonalnej. Można rzec, że tą sferę pozostawiono artystom, którzy wedle Josepha Campbella ${ }^{2}$ zastąpili dawnych szamanów i proroków i przejęli niejako rolę przekazicieli mitu. A artyści od zawsze przekraczali tę sferę, próbując niekiedy przejąć rolę mędrców. $Z$ tym że, a na tym opiera się wiele nieporozumień, wielkie dzieło artystyczne jest zazwyczaj mądrzejsze od swego twórcy. Czyż nie ma racji Milan Kundera, kiedy stwierdza, że od końca XX wieku filozofia straciła kontakt $z$ konkretnym życiem i oddaliła się od świata, zatracając się w abstrakcjach? „Duch Europy i jej mądrość ucieleśniony jest teraz nie w myśli filozoficznej, ale w powieściach takich jak „Ulisses”, „Czarodziejska góra”, „Człowiek bez właściwości”, „Zamek”, „Lunatycy”, „Kosmos”.

Jeśli uznamy nawet, że Kundera przesadził, to jednak warto podkreślić, że artyści pełnią w kulturze rolę systemów wczesnego ostrzegania. Przez artystę przemawia nie tylko duch czasu, ale też duch przyszłości, którego nie rozumie, a który manifestuje się jako wewnętrzne napięcie twórcy, wyrażające się w akcie kreacji, skryte za światem symboli, metaforą: słowem, obrazem, dźwiękiem etc.

Interpretując „Mit państwa” Cassirera Sławomir Raube wskazuje na podobną rolę filozofa w kulturze, który jednak w przeciwieństwie do artysty kieruje się przejrzystą, nieraz aż do bólu, świadomością. Jak pisze Autor: „Obowiązkiem filozofii jest stała obserwacja kulturowych ruchów tektonicznych i ostrzeganie przed naruszeniem delikatnej równowagi pomiędzy tym, co racjonalne a mrocznymi siłami mitycznymi" ${ }^{4}$.

\footnotetext{
${ }^{2}$ Por. J. Campbell, Potegga mitu, przeł. I. Kania, Sigma, Kraków 1994.

${ }^{3}$ M. Kundera, Zachód porwany albo tragedia Europy Środkowej, „Zeszyty Literackie” nr 5/1984, s. 15 .

4 S. Raube, Powracajacy mit: idea regresu w filozofii kultury Ernsta Cassirera, „Kultura i wartości” nr 2(10)/2014, s. 32.
} 
Wydaje mi się jednak, że ta tzw. delikatna równowaga (dlatego można mówić o delikatnej) w rzeczy samej opiera się na dynamicznym ścieraniu się przeciwieństw. Przeciwieństwo pomiędzy opartym na emocjach i intuicji myśleniu mitycznym a myślą racjonalną podlega prawu enancjodromii. Enancjodromia (z greki „bieg naprzeciw”) jest pojęciem charakterystycznym dla filozofii Heraklita, który w ten sposób określał grę przeciwieństw w obrębie tego, co się wydarza. Wszystko, co jest, przechodzi w przeciwieństwo samego siebie. W psychologii Junga, dzięki któremu to pojęcie dostało „drugie życie”, enancjodromia oznacza „(..) występowanie nieświadomego przeciwieństwa, zwłaszcza wtedy, gdy jeden element następuje po drugim"s. Można rzec, że nieświadome przeciwieństwo naszej świadomej postawy jest sprawcą naszego losu. $\mathrm{Na}$ przykład przeciwieństwem funkcji myślenia jest funkcja uczucia. Ludzie, dla których funkcja myślenia stała się funkcją główną i wchodzą w kontakt ze światem przede wszystkim za pomocą myślenia intelektualnego, funkcja uczucia, jako funkcja niższa, jest ich „cieniem”, ich „piętą achillesową”. Tam, gdzie władzę przyjmują emocje i uczucia pozostają ułomnymi. Na ten stan rzeczy można byłoby przytoczyć całkiem sporo dowodów, np. ilu wybitnych intelektualistów fatalnie wybiera, jeśli chodzi o swe związki miłosne czy sympatie dla ruchów społeczno-politycznych (np. bratanie się intelektualistów z komunistami, narodowcami czy neoliberałami, którzy odwołują się do tego, co najbardziej w naturze ludzkiej niepożąanane: od przemocy po chciwość). Wystarczy nieraz jeden błąd popełniony w stanie obniżonego progu świadomości (silne wzburzenie, zakochanie, przemęczenie, intoksykacja etc.) i okazać się może, że ten błąd w o wiele większym stopniu determinuje nasz los niż najbardziej przemyślane, świadome, wybory. Oczywiście zdarzenia zmieniające i wyznaczające nasz los mogą być również pozytywne (na przykład wglądy twórcze i odkrycia naukowe dokonywane pod wpływem intensywnych doświadczeń). W przypadku najbardziej racjonalnego myśliciela wystarczy naruszyć „wymyślone” dogmaty, byśmy doświadczyli z jego strony dzikiej erupcji emocji. $Z$ drugiej strony u osób zdomi-

\footnotetext{
${ }^{5}$ C. G.Jung, Typy psychologiczne, thum. R. Reszke, Warszawa 1997, s. 477.
} 
nowanych przez funkcję uczuć i emocji myślenie przybiera formę najprzeróżniejszych urojeń.

Ze zjawiskiem enancjodromii, które przekracza sztuczne granice Wschodu i Zachodu, spotykamy się nie tylko w poglądach Heraklita i Junga, lecz również w taoizmie i w buddyzmie (szczególnie w buddyzmie czan). Niekiedy te zjawisko oddawane jest za pomocą takich terminów jak ,jedność przeciwieństw” (moim zdaniem brzmi zbyt statycznie) czy dialektyczny monizm. To, co łączy główne założenia psychologii Junga z ideami taoistycznymi, buddyzmu mahajany i heraklitejskimi to założenie, że jedność i dwoistość są, jeśli nie identyczne, to pokrewne sobie; jedność pojawia się w dwoistości, zaś dwoistość sprowadza się do jedności. "Jak wszelka energia jest rezultatem napięcia między przeciwnymi biegunami, tak i dusza jest wewnętrznie spolaryzowana; jest to konieczna przesłanka żywotności duszy. (...) Polaryzacja jako warunek życia (...) staje naprzeciw jedności ja, która nie dość, że jest krucha, to jeszcze jest wynikiem trwającego tysiące lat procesu, zresztą istnieje ona dzięki przedsięwzięciu niezliczonych środków bezpieczeństwa”.

Twórca psychologii analitycznej argumentuje, że energia leżąca u podstaw świadomego życia jest wcześniejsza niż życie, dlatego też zrazu jest nieświadoma. Proces uświadomienia pojawia się w swych początkach w formach projekcyjnych (bogowie, demony etc.). Jeśli ktoś uznaje, że treści świadomości są jedyną formą istnienia to, zdaniem Junga, naraża się na niebezpieczeństwo inflacji (boska moc może być przypisywana pieniądzom, własności, określonej ideologii etc.). Nawiązując, w jednym ze swych Seminariów ${ }^{7}$ do słynnego zdania Heraklita, że „Wojna jest ojcem wszystkich, wszystkich królem; jednych ukazuje jako bogów, innych jako ludzi, tych czyni niewolnikami, tamtych wolnymi”, Jung porównuje enancjodromię do piekła, przywołując symbolikę ognia. Jednak w piekle tym znajdują się również klejnoty. „Czymże są namiętności i emocje?

${ }^{6}$ Tenże, Wspomnienia, sny, myśli. Spisane i podane do druku przez Aniele Jaffé, przeł. R. Reszke i L. Kolankiewicz, Warszawa 1997, s. 300.

${ }_{7}$ Tenże, Psychologia kundalini-jogi. Wedtug notatek z seminariów 1932 opracowat Sonu Shamdasani, przeł. R. Reszke, KR, Warszawa 2003, s. 120.

${ }^{8}$ Za: W. Jaeger, Teologia wczesnych filozofów greckich, przeł. J. Wocial, Homini, Kraków 2007, s. 185. 
Są źródłem ognia, zasobnika energii. Człowiek, który nie ma żaru w sobie jest niczym - jest to osobnik płaski, śmieszny, dwuwymiarowy. Człowiek musi płonąć, nawet jeśli w ten sposób robi z siebie błazna”. W „Psychologii i religii” stwierdza, że „Od czasów Heraklita życie przedstawiane jest jako pyr aeizoon, to znaczy wiecznie żywy ogień"10.

W słynnej „Sutcie o płonięciu”" Budda porównuje procesy życiowe do płomienia i spalania. Zmysły i umysł oraz ich obiekty i odpowiadające im świadomości płoną ogniem pożądania, awersji, ułudy, odrodzeń, starzenia się, śmierci, żalu, cierpienia, bólu, strapienia, rozpaczy. Płoną również uczucia, zarówno przyjemne, nieprzyjemne, jak i neutralne. Spalają nas myśli, które wypełniają nasze głowy. Jednym słowem - wszystko płonie.

Fascynacja Cassirera mitem („Esej o człowieku”), i wskutek doświadczeń z ideologią narodowego socjalizmu, jego późniejsza podejrzliwość w stosunku do mitu i nadawanie nadmiernej wartości myśleniu racjonalnemu osadzają się na obłędnym zachodnioeuropejskim uwarunkowaniu, które prowadzi do dysocjacji, spotęgowanej jeszcze przez wiktoriańskich hipokrytów, między myślą a emocją. Uwięzieni w kręgu myśli zachodnioeuropejskiej zapominamy, że stan pozytywny można osiągnąć nie poprzez wypieranie i tłumienie tego, co negatywne, lecz przez transformację negatywnego. Jiddu Krishnamurti zwrócił uwagę na pewien uwarunkowany kulturowo mechanizm, który ujawnia się m. in. w języku: „Przez negację rodzi się coś stricte pozytywnego (...) Dzięki rzeczywistej negacji tego, co niemoralne, rodzi się moralność"12. A to znaczy, że do miłości prowadzi negacja nienawiści a nie dążenie do miłości. Ireneusz Kania ${ }^{13}$ analizując palijskie słowo „averena” (życzliwość, miłość, dobroć) zwraca uwagę na to, że ma ono konstrukcję negatywną. Składa się z partykuły prywatywnej (od łac. privatio brak) a i słowa vera (nienawiść). Zatem „averena” to „nie - nienawiść”, „brak nienawiści”. W refleksji religijno-etycznej wczesnego buddyzmu (również i hin-

${ }^{9}$ C.G. Jung, Psychologia kundalini-jogi, wyd. cyt., s. 120.

${ }^{10}$ Tenże, Psychologia a religia, przeł. J. Prokopiuk. Wrota, Warszawa 1997, s. 49.

${ }^{11}$ Por. I. Kania, Muttavali. Wypisy z ksiag starobuddyjskich, Aletheia, Warszawa 2007, s. 134.

${ }^{12}$ J. Krishnamurti, Catkowicie inny sposób życia, przeł. R. Kubik, KOS, Katowice 2008, s. $60-61$.

${ }^{13}$ Por. I. Kania, dz. cyt., s. 300. 
duizmu) jest sformułowanych w ten sposób wiele istotnych, pozytywnych pojęć. W palijskim „spokój” to „akodha” (brak gniewu, nie - gniew); „zdrowie” „arogya” (brak choroby, nie - choroba). W grece także występuje partykuła prywatywna $a$ (nie, bez). Żeby jednak odczuć różnicę warto przywołać kilka słów. „Agnosia” (brak poznania, ignorancja), „astenia” (niemoc, choroba, gdy tymczasem „stenos” to siła, tężyzna, moc). O ile jeszcze można porównać z sobą słowo „agnoia” (niewiedza) z sanskryckim terminem „avidia” (niewiedza, głupota), to zazwyczaj, w przeważającej mierze w grece poprzez wykorzystanie partykuły $a$ pojęcia pozytywne zmieniają swe znaczenie na negatywne. W języku polskim używamy jako partykułę prywatywną nie. Mówimy o kimś, że jest niedobry (w znaczeniu zły), niegrzeczny, niemoralny, nierozumny. Osiąamy w ten sposób złudzenie, że zło jest negacją dobra czy niemoralność negacją moralności, tak jakbyśmy na zawołanie posiadali pozytywne cechy, czyli to, co można zanegować. W większości nowożytnych języków Europy, a proces ten rozpoczął się już od czasów posokratejskich (szczególnie widać to w filozofii Arystotelesa) zostały powymyślane pojęcia na określenie właściwości przeciwnych w stosunku do pojęć pozytywnych (tzw. nazwy negatywne), ale w taki sposób, by żywić złudzenie, że pomiędzy przeciwieństwami nie ma żadnych styczności. W ten sposób myśl europejska poczęła tracić świadomość konwencjonalnego charakteru języka. Doszło do tego, czego obawiało się wielu filozofów buddyjskich, mianowicie do „ontologizacji pojęć abstrakcyjnych”14. Tym samym rozpoczął się proces odrywania się filozofii od mądrości. Czyż coraz bardziej nie sprzyja temu procesowi utrata kontaktu nie tyko $z$ naturą, ale przede wszystkim tracenie kontaktu przez licznych myślicieli z własnym ciałem i emocjami? Chyba jednak warto pójść za tymi wskazówkami Nietzschego:

"Jak najmniej siedzieć, nie wierzyć żadnej myśli, która się nie urodziła na wolnem powietrzu i przy swobodnym ruchu - jeśli i mięśnie przy tym święcie nie uczestniczą. Wszystkie przesądy pochodzą z kiszek. - Cierpliwość pośladków - rzekłem to już raz - to właściwy grzech przeciw Duchowi Świętemu.”15

\footnotetext{
${ }^{14}$ Por. tamże, s. 300.

${ }^{15}$ F. Nietzsche, Ecce homo, przeł. L. Staff, Warszawa, Mortkowicz, Warszawa 1912, s. 28.
} 
"Jeno wychodzone myśli są coś warte."16

Jak już wspomniałem, podstawą myślenia mitycznego są emocje, intuicja i wola (oczywiście w znaczeniu schopenhauerowskim jako popęd, żądza, która najpierw chce, a dopiero potem poznaje), ale również poczucie jedności życia człowieka i przyrody (natury, kosmosu). ${ }^{17}$

Charakterystyczne dla tego myślenia jest utożsamienie tego, co rzeczywiste i wyobrażone. Cassirer pisze o przenikającej myślenie mityczne zasadzie metamorfozy ${ }^{18}$. Wszystko jest możliwe, wszystko może zmienić się we wszystko, część staje się tym samym co całość. Cassirer był świadomy tego, że myśl racjonalna jest zbudowana na „glebie wulkanicznej”, pod którą kipi bardziej pierwotna myśl mityczna. Dlatego też, zdaniem Cassirera, trzeba być przygotowanym na wstrząsy i kataklizmy. Zdaniem Freuda i Junga świadomość jest ledwie wysepką na oceanie nieświadomości. I po to, by nie pogrążyć się w szaleństwie i zachować choć pozór panowania nad sobą trzeba wkraczać w nieświadome, by je oswajać i transformować. Twórcy psychologii głębi, dzięki połączeniu własnej autoanalizy i doświadczeń praktycznych z pacjentami, wiedzieli jednak, że przed „cieniem” (zarówno indywidualnym jak i zbiorowym) nie można uciec, ani też nie da się go pokonać. Walcząc z nim, tylko go się wzmacnia. Można go jedynie rozpoznać i powoli rozmontować, niczym saper unieszkodliwiający niebezpieczny ładunek. Z tym że „cień” w każdej chwili może się odrodzić i popsuć święto zaślubin $z$,jasną stroną mocy”.

Ernst Cassirer ujmuje kulturę jako system powiązanych ze sobą form symbolicznych. Formy te tworzą otaczającą nas rzeczywistość, właściwe nasze środowisko ${ }^{19}$. Czas, przestrzeń, przyczynowość, rzecz i jej własności są formami ujmowanymi ze względu na jakość; zaś mit, religia, nauka, historia, język - ze względu na modalność.

${ }^{16}$ Tenże, Zmierzch bożyszcz, czyli jak filozofuje się mtotem, przeł. S. Wyrzykowski, Warszawa 1910, s. 10.

${ }^{17}$ Zob. M. Bal-Nowak, Mit jako forma symboliczna w ujęciu Ernsta Cassirera, Wydawnicwo Nomos, Kraków 1996, s. 81.

${ }^{18}$ E. Cassirer, Esej o cztowieku, przeł. A. Staniewska, Czytelnik, Warszawa 1977, s. 175.

${ }^{19}$ Zob. E. Cassirer, Pojęcie formy symbolicznej w budowie nauk humanistycznych, [w:] Symbol i jezzyk, przeł. I red. B. Andrzejewski, Wydawnictwo Naukowe IF UAM, Poznań 1995, s. 11-43. 
Istota ludzka opętana przez myślenie mityczne może odczuwać wszechmoc i wszechobecność. Może jej się wydawać, ze jest w centrum wydarzeń, a nawet, że wywiera wpływ na świat. U jednostki stan ten kojarzy się z chorobą psychiczną, u większej grupy, niestety, wręcz przeciwnie. Cassirerowskie myślenie mityczne ma wiele wspólnego z jungowskim opisem osób, których psychikę zdominowała funkcja uczucia. Jednak należy zauważyć, że konflikt pomiędzy związanym $z$ mitem światem obrazów i emocji a myśleniem racjonalnym jest konfliktem archetypowym, wyrastającym wprost z „serca” ludzkiej natury. Tym niemniej to myśl racjonalna pozostaje w służbie najbardziej irracjonalnych mitów, choć czasem może wydawać się inaczej.

Jakby na to nie patrząc enancjodromia to piekło, gdzie, parafrazując Schopenhauera, jedni odgrywają role męczonych dusz a inni diabłów. Enancjodromia to świat samsary, cierpienia, pułapki nadmiaru i niedostatku, przesytu i głodu, ciągłego braku czegoś. To nasz świat, po którym błąkają się, rozumne i jednocześnie szalone istoty (homo sapiens-demens), poszukując obiektów materialnych i niematerialnych, łudząc się, że przy ich pomocy zaspokoją swe nienasycone pragnienia. Najbardziej przerażające jest to, że do koszmaru prowadzą nie tylko utopie odwołujące się do silnie działających na emocje czarno - białych mitów krwi, rasy, „pomazańców bożych”, ale również projekty oparte na jak najbardziej racjonalnych przesłankach, które okazują się innymi przebraniami ludzkich pragnień związanych z długim życiem (nieśmiertelnością), zdrowiem, szczęściem, materialnym dostatkiem. Koszmar związany z ziszczaniem się tych pragnień obserwujemy w dwóch słynnych antyutopiach: w „Nowym wspaniałym świecie” Aldousa Huxleya i współczesnym „Kręgu” Dave’a Eggersa. Ze względu na tematykę mego szkicu, więcej miejsca poświęcę tej drugiej pozycji, już sławnej, ale mniej znanej, której treść koresponduje z życiem człowieka ery cyfryzacji. Warto jednak przypomnieć, że w powieści Huxleya pojawia się wizja natury jako produktu konsumenckiego: „Warunkujemy masy na niechęć do przyrody (...) Równocześnie jednak wykształcamy w nich upodobanie do sportów na ło- 
nie natury. Dbamy przy tym o to, by sporty te wymagały użycia skomplikowanych przyrządów"20.

Podejście do natury opiera się zatem na racjonalnych i brutalnie pragmatycznych przesłankach. Kontemplacja naturalnego piękna jako czynność darmowa i bezproduktywna została uznana za zaburzenie psychiczne i jako potrzeba - wypleniona. Spełnienie tego proroctwa zaczęło się najszybciej. Mimo pespektywy nadchodzącej klęski ekologicznej dla licznej rzeszy konsumentów natura to nowe trasy narciarskie, sprowadzające śmierć na górskie lasy, polany rozjeżdżane przez quady i dewastowane przez developperów, betonowe ścieżki dla niedzielnych rowerzystów i miłośników nordic walking i mijane ludzkie istoty zaopatrzone w drogie oprzyrządowanie i markowe stroje. Natura jest tylko najmniej potrzebnym dodatkiem do romansu z sobą samym, manifestowania pozycji społecznej i pogoni za orgazmicznym odprężeniem. Spotykamy też w tej antyutopii wizję idealnej substacji, zwanej somą, produktu farmakologicznego, dzięki któremu podtrzymywany jest w społeczeństwie stabilny stan szczęścia i niemożność doświadczenia zwątpienia: „Wszystkie zalety chrześcijaństwa i alkoholu, żadnej z ich wad (...) „Uwalniamy się od rzeczywistości, kiedy tylko zechcemy i takoż wracamy, bez bólu głowy i bez potrzeby mitologii”21.

Społeczeństwo odcięte jest od mądrości kultury, zarówno tej, którą można nabyć dzięki lekturze pism, jak i od żywego przekazu mędrców i nauczycieli. Młodzieży zaleca się czytanie tylko fachowych książek, zaś samotna kontemplacja utworu poetyckiego czy traktatu filozoficznego jest rzeczą podejrzaną i niewskazaną jako nieprzyzwoita samotna zabawa. A kandydaci na mędrców?: „Praca, zabawa... po sześćdziesiątce nasze siły i gusta, pozostają takie jak w wieku lat siedemnastu. W dawnych złych czasach starzy ludzie usuwali się z życia, szli na emeryturę, poświęcali się religii, spędzali czas na myśleniu... na myśleniu! (...) Dziś oto postęp, starzy ludzie pracują, starzy ludzie kopulują, starzy ludzie nie mają czasu, nie mają siły wytchnienia od przyjemności, okazji do tego, by usiąść i zacząć rozmyślać; gdyby zaś przez przypadek pojawiła się taka szczelina czasu w spoistej substancji ich rozrywek, zawsze pozostaje soma, pół grama na popo-

\footnotetext{
${ }^{20}$ A. Huxley, Nowy wspaniaty świat, przeł. B. Baran, Kraków 1988, s. 28.

${ }^{21}$ Tamże, s. 58-59.
} 
łudnie, gram na weekend, dwa gramy na podróż na przewspaniały Wschód, trzy na mroczną wieczność na księżycu; wracając znajdą się po drugiej stronie szczeliny, bezpieczni, na twardym gruncie codziennej pracy i rozrywek, biegając z jednego czuciofilmy na drugi, od jednej sprężystej dziewczyny do innej, od zawodów elektromagnetycznego golfa do..."22.

W tym idealnym świecie rozpowszechniona jest wiara w szczęśliwość jako Dobro Najwyższe. Szczęśliwość nie osiąga się ani przez pogłębienie świadomości, ani poszerzenie wiedzy, lecz w sposób brutalnie behawiorystyczny, poczucie szczęścia jest reakcją organizmu na bodziec zewnętrzny (substancja farmakologiczna, seanse czuciofilmów, szereg zabiegów, które sprawiają, że umiera się wyglądając młodo: stymulacje, transfuzje, ochrona przed chorobami).

Jak wyjaśnia Johnowi zwanemu Dzikusem (z racji przywiązania do tradycji kultury) jeden z dziesięciu zarządców Republiki Świata Mustafa Mond: „Nie można produkować aut nie mając stali, nie można tworzyć tragedii bez społecznej niestabilności. Ludzie są szczęśliwi; otrzymują wszystko, czego zapragną, a nigdy nie pragną czegoś, czego nie mogą otrzymać”23.

Społeczeństwo jest utrzymywane w błogiej niewiedzy o namiętnościach i starości. Bez matek, ojców, mężów, żon, dzieci, kochanek i kochanków, wszyscy, na swój, zależny od swojej kasty sposób, zamożni, bezpieczni, zawsze zdrowi. Lekka praca, potem soma, gry, seks bez ograniczeń, czuciofilmy. Należy zawsze lubić to, co nowe, choć jest głupie, helikoptery na ekranach, pocałunki aktorów etc. Niepotrzebne i niecenione są rzeczy stare, szczególnie, gdy są piękne, ponieważ piękno wabi... „Dziś ludzie nigdy nie są samotni (...) Sprawiamy, że nie znoszą samotności; urządzamy ich życie tak, że jest jeszcze niemożliwe, by kiedykolwiek w nią popadli”24. Te dwa ostatnie zdania brzmią jakby współczesny opis ludzi uwięzionych z własnej woli na smyczach portali społecznościowych. A że człowiek ma od czasu do czasu potrzebę przeżywania stanów niepokoju i gwałtownych uczuć, Huxley wprowadza na łamy powieści interesujący produkt farmaceutyczny: SGN (Surogat Gwałtownej Namiętności). Raz

\footnotetext{
${ }^{22}$ Tamże, s. 59-60.

${ }^{23}$ Tamże, s. 229.

${ }^{24}$ Tamże, s. 244.
} 
w miesiącu system krwionośny człowieka jest nasycany adrenaliną, dzięki czemu otrzymujemy równoważnik psychologiczny lęku i wściekłości. Oczywiście dla wielu konsumentów gier komputerowych i pornograficznych klipów sama wirtualna rzeczywistość przez swą atrakcyjność jest wystarczającym równoważnikiem lęku i wściekłości.

W takim wspaniałym świecie jakże absurdalnie brzmi wołanie Dzikusa: „Ja nie chcę wygody. Ja chcę Boga, poezji, prawdziwego niebezpieczeństwa, wolności, cnoty. Chcę grzechu.

- Inaczej mówiąc (...) domaga się pan prawa do bycia nieszczęśliwym. (...) Nie mówiąc o prawie do starzenia się, brzydnięcia i impotencji; o prawie do syfilisu i raka; o prawie do niedożywienia, do bycia zawszonym i do życia w niepewności jutra; o prawie do zapadnięcia na tyfus, do cierpienia niewysłowionego bólu wszelkiego rodzaju. (...)

- Domagam się prawa do tego wszystkiego (...)"25.

Jest w sytuacji bez wyjścia i będąc tego świadomy coraz bardziej radykalizuje swoje postawy, tak jak obecnie mieszkaniec Europy Środkowej, im bardziej poddawany jest presji ideologii neoliberalnej, tym bardziej poszukuje ratunku i dowartościowania w czarno-białej utopii mitów plemiennych i narodowych. Dzikus umartwia się, biczuje w pustelni, lecz nie jest pozostawiony samemu sobie. Dla pustelników nie ma już miejsca. Jako atrakcja medialna, oglądany, wręcz zaszczuty, odnajduje wyjście w akcie samobójczym.

Niemal kopię Dzikusa, utkanego na miarę ponowoczesności, odnajdziemy i w „Kręgu” Eggersa. Ale najpierw warto siebie zapytać: Czy rzeczywiście nasze życie przeniosło się do sieci? To nie życie przeniosło się do sieci, to umysły wielu z nas tam zamieszkały, próbując zaprzeczyć, że są tylko niebezpiecznie bardziej rozgarniętymi dziećmi Matki Natury, a tymczasem są wciągani przez nią perfidną pułapkę, zbudowaną z ułudy efektywności i racjonalności.

W psychopatologii terminem logorea (od 'logos' - słowo i 'rhoà' - rzeka) określa się patologicznie szybkie i bezwładne wypowiadanie się, słowotok. Polski antropolog i kulturoznawca Wojciech J. Burszta tymczasem pokazuje nam,

\footnotetext{
25 Tamże, s. 249.
} 
że żyjemy w kulturowej, medialnej logorei. Logorea „To mieszanina słowoobrazów z metakomentarzami bez granic" ${ }^{26}$. Słowoobrazy zawłaszczają nasze wyobrażenia przeszłości, teraźniejszości i możliwej przyszłości. Poddając refleksji pracę, konsumpcję, czas wolny i przemysł turystyczny Burszta wplata w to fascynujące krótkie rozważanie na temat idei miejsca. W tym celu przywołuje greckie terminy: topos (miejsce abstrakcyjne, jakiś konkretny punkt na mapie) i, rzadziej dzisiaj używane, skazane na zapomnienie, chora („miejsce egzystencjalne, ze wszystkimi cechami czyniącymi go wyjątkowym)”27. To „chora sprawia, że żyjący tam ludzie są innymi, niż byliby w innych miejscach. Jest równocześnie tak, że ludzie żyjący w chora także nań wpływają, zmieniają ją, odciskają na niej swoje piętno. (...) Rezultat tej nieustającej interakcji starożytni zwykli zwać 'poezją świata', do którego warto było docierać"28.

Burszta uświadamia nam, że współczesny człowiek jest obojętny na specyfikę miejsc i widzi tylko abstrakcyjne przestrzenie, czemu oczywiście sprzyja nowoczesna wizja świata rozczłonkowanego stworzonego z bezwładnych, niepowiązanych $z$ sobą elementów. W monografii „Kultura manii” ${ }^{29}$ pozwoliłem sobie na wprowadzenie pojęcia ,imagopatii”. Imagopatami możemy nazwać tych, którzy są bez reszty pochłonięci światem logorei. Zatem imagopatia jest stanem, w którym rzeczywistość wirtualnych „gadających” obrazów staje się jedyną rzeczywistością, jaką doświadcza podmiot, deprecjonując to, co istnieje poza ekranem. Tym samym to, co zawsze było traktowane jako realne zostaje zdegradowane do statusu rzeczy odrealnionych (rodzina, natura, przestrzeń mieszkalna, materialne dziedzictwo kulturowe etc.). Imagopatia to stan, w którym najbardziej realne stają się bóle i rozkosze zadawane przez świat wirtualnych obrazów. Jednak rozkosz nie ulega takiej intensyfikacji jak ból, który doświadcza się za pośrednictwem świata wirtualnego, ponieważ ból ten wynika $z$ uświadamianiem sobie własnego wybrakowania. Paradoksalnie, jednostka taka żywi iluzje, że w łatwy sposób te wybrakowanie zapełni, wystarczy tylko coś kupić, robić

\footnotetext{
${ }^{26}$ W. J. Burszta, Preteksty, Gdańsk 2015, s. 33.

${ }^{27}$ Tamże, s. 134.

${ }_{28}$ Tamże, s. 134.

${ }^{29}$ Zob. T. Olchanowski, Kultura manii, Warszawa 2016.
} 
to, co czyni zapośredniczony autorytet, a nawet $\mathrm{w}$ jednej chwili przemianie ulegnie na piękną powłokę idola, własne, szpetne ciało. Nawet zaczyna roić sobie, że siłą woli zapanuje nad układem wegetatywnym, erekcją, pobudzeniem seksualnym, orgazmem, pozbędzie się w oka mgnieniu lęków i zahamowań i tego wszystkiego, co w sobie nie znosi, a nawet wierzy, że siłą woli jest w stanie panować nad tym, co myślą inni. Jednocześnie ci, w większej części anonimowi, inni za pomocą negatywnych czy pozytywnych opinii poczynają sterować stanami emocjonalnymi jednostki. Cóż, skoro już na drugie urodziny, a nawet i wcześniej otrzymuje się w prezencie tablet do zabawy, a w okresie niemowlęctwa i wczesnego dzieciństwa jest się wyprowadzanym na spacer nie tyle przez rodzica, co jego znajomych z Facebook'a i ekran smartfona, to świat natury staje się senną marą, czymś, co należy szybko pokonać i obudzić się w cyfrowym świecie nieograniczonych możliwości.

Zdaniem klasyków psychoanalizy jednym z najbardziej istotnych mechanizmów obronnych jest projekcja, która wiąże się z rzutowaniem wewnętrznych stanów i wyobrażeń z nieświadomości na otoczenie. Sam w sobie ten mechanizm może być normalny, patologiczny, może też stanowić obronę przed lękiem, jednak generalnie zubaża osobowość czyniąc ze świadomości jednostki wąską smugę światła, zagrożoną przez mroczną potęgę nieświadomego. W prymitywnym, archaicznym stadium asymilacji projekcji obrazy wyobraźni i marzeń sennych są traktowane jak rzeczywiste. Jednostka żywi mniemanie, że to, co widzi w innej osobie, rzeczywiście takie jest. Następuje przemieszanie porządku wewnętrznego $\mathrm{z}$ porządkiem zewnętrznym. U zdrowego człowieka poczucie te występuje właściwie tylko $\mathrm{w}$ snach, zaś w chorobach psychicznych emocje nie tylko są doznaniami wewnętrznymi i subiektywnymi, lecz stają się faktami. U imagopatów mamy do czynienia $z$ uwięzieniem psyche na dobre i na złe w stadium archaicznym, z tym że zamiast obrazów wyobraźni i marzeń sennych bardziej rzeczywiste stają się obrazy odbierane i konsumowane za pośrednictwem monitorów. Świadomość imagopaty angażują jej wirtualne widma, które uwodzą swym urokiem, a potem dręczą, psychicznie niszczą, a nawet sprowadzają śmierć. 
W psychoanalizie definiuje się imago jako „Nieświadomy wzorzec kierujący sposobem postrzegania innych ludzi”30. Ten nieświadomy wzorzec nie tylko jest przyswajany przez nas w procesie wychowania i socjalizacji, który towarzyszy naszej ontogenezie (przede wszystkim w okresie dzieciństwa), ale też jego zasadnicza forma jest dziedziczona $\mathrm{z}$ pokolenie na pokolenie. Zatem nie tylko rzeczywiste zdarzenia, mające miejsce w rodzinie, formują ten wzorzec, lecz również nieświadome fantazje, wypływające $z$ nieznanych źródeł i będące reakcjami nie tylko na to, co się w tej rodzinie dzieje. Lajos, Edyp, Elektra i inni greccy bohaterowie, a nawet bogowie, inkarnują się również w psyche rodziców i dzieci XXI wieku, rozgrywając swe konflikty. $\mathrm{Na}$ ile ten nieświadomy wzorzec, mający wiele wspólnego $\mathrm{z}$ jungowskimi archetypami, ulega przekształceniom w wyniku wchłonięcia ludzkich umysłów w świat wirtualny, (i co z tego wynika), prawdopodobnie dopiero przekonamy się, jako że mamy do czynienia ze zjawiskiem stosunkowo młodym, po kilku dekadach, kiedy w dorosłe życie wkroczy pokolenie dopiero co poczęte.

W powieści Davida Eggersa „Krąg” na bazie zdeformowanych przez ducha czasu kultury cyfrowej, ludzkich pragnień do stałego monitorowania, podglądania i komunikowania się wyrósł potężny korporacyjny potwór „Circle”. Ta wielka informacyjno - medialna potęga sprawuje faktycznie władzę nad światem, dzięki monopolowi na przekaz informacji i totalną przejrzystość każdego obywatela. Wchodząc do siedziby Korporacji, luksusowego kampusu położonego nad Pacyfikiem, spotkamy reklamowe komunały typu: „Nie rezygnuj z marzeń”, „Nie stój z boku”, „Znajdź wspólnotę” (a nawet „Oddychaj”). Szczyt korporacyjnej drabiny stanowi tzw. Banda Czterdzieściorga (40 wybitnych umysłów pracujących na potęgę Circle). A nad nimi, znajduje się Trzech Mędrców, założycieli firmy. Ty Gospodinov, cudowne dziecko i wizjoner, graniczny przypadek zespołu Aspergera, człowiek, który przejrzał na oczy za późno, kiedy, niczym uczeń czarnoksiężnika powołał do życia potęgę, nad którą stracił kontrolę, a jego pragnieniem było ucywilizowanie sieci. $Z$ tego powodu opracował specjalną aplikację, wszystkie potrzeby i narzędzia użytkownika zostały wrzucone do jed-

\footnotetext{
${ }^{30}$ S. Fháner, Stownik psychoanalizy, przeł. J. Kubitsky, Gdańsk 1996, s. 68.
} 
nego garnka - TruYou - jedno konto, jedna tożsamość, jedno hasło, jeden system płatności na osobę. Koniec fałszywych tożsamości, nie ma trolli i hejterów, widzimy i jesteśmy widziani, znane są nasze nawyki, stan zdrowia, produkty, które konsumujemy, daje to olbrzymie możliwości dla marketingu. Drugi z mędrców to Eamon Bailey, twarz firmy, infokomunista, dla którego wiedza jest wspólną własnością i nikt nie może jej posiadać dla siebie. Wszyscy ludzie mają być powiązani, a odpowiedzi na istotne życiowe pytania poszukuje się u innych. No i wreszcie trzeci: Tom Stenton - globalny biznesmen, przypominający nowojorskiego maklera giełdowego, o bezwzględnej kapitalistycznej ambicji (90\% informacji o świecie dociera do odbiorców za pomocą „Circle”). Na dobrą sprawę, ze względu na swe cechy charakteru, czyż tych Trzech Mędrców nie byłoby doskonałą metaforą idealnego zespołu badawczego? Aspołeczny geniusz, mózg przedsięwzięcia, prospołeczny infokomunista, dzielący się z innymi informacjami na temat przedsięwzięcia, potrafiący zarazić innych swym ideologicznym entuzjazmem, no i ten, który potrafi z tego wszystkiego osiąnąć maksymalny zysk.

Główna bohaterka to przerażająco podatna na propagandę, inteligentna idiotka, pnąca się szybko w górę, młoda dziewczyna Mae Holland, entuzjastka nowego porządku, mająca wiele z Paszki Morozowa, ponieważ, m. in. zdradza i wydaje kochanka dla dobra Korporacji. Jest i ponowoczesny Dzikus, krytyk systemu, Mercer, prowincjonalny rzemieślnik, producent żyrandoli. O zarządcach kultury cyfrowej Mercer mówi, że wytwarzają nienaturalnie skrajne potrzeby towarzyskie ${ }^{31}$. Kontakty towarzyskie w sieci porównywane są do przekąsek, które niczego nie poprawiają, nie krzepią, są pustymi kaloriami w cyfrowo społecznościowej postaci. Jednak uzależniają (stają się sztucznym popędem).

„Świat doprowadził się do zidiocenia” ${ }^{32}$ - oto słowa, które mogą być głównym mottem poglądów wypowiadanych przez "ponowoczesnego Dzikusa” Mercera. Mamy do czynienia z kulturą, w obrębie której główny nurt komunikacji opiera się na plotkach, pomówieniach i domysłach. Zdaniem Mercera wszyscy obecnie zatrzymali się na poziomie rozwojowym gimnazjalistów („po-

\footnotetext{
${ }^{31}$ Por. D. Eggers, Krag, przeł. M. Fedyszak, Katowice 2015, s. 135.

${ }^{32}$ Tamże, s. 134.
} 
doba się”; „nie podoba”; buźki). A warto pamiętać, że w fazie dojrzewania płciowego mamy do czynienia $z$ umysłem totalitarnym, nietolerancyjnym, postrzegającym świat przy pomocy czarno - białego schematu (oni - my, starzy młodzi, wszystko albo nic etc.). Paradoksalnie ta rozbuchana komunikacja prowadzi do... autyzmu społecznego ${ }^{33}$. Na przykład tak modne ignorowanie towarzystwa ludzi siedzących obok przy stole, ponieważ ważniejszą czynnością stało się „podpięcie się do smyczy” i wyszukiwanie informacji i obrazów na ekranie. W powieści Eggersa doświadczymy wraz z bohaterką sytuacji, kiedy to japiszon przeżywający romans z samym sobą na drugiej półkuli, w pięknej scenerii, obchodzi bardziej (i jest bardziej realny) niż przebywający obok partner, ojciec, matka, dziecko...

Mercer chce żyć poza. Jest zszokowany, gdy zdjęcia własnych wytworów, odnajduje w sieci, wśród buziek i komentarzy, umieszczone tam wbrew jego woli. Jesteśmy w świecie, w którym: „Tajemnice to kłamstwa” / Dzielenie się - lek na każde strapienie/ Prywatność to kradzież”34.

Idealnym życiem jest życie przejrzyste. Wątpią w przejrzystość tylko ci, którzy mają nieczyste sumienie.

Odwołując się do większego poczucia bezpieczeństwa (już Freud miał świadomość tego, że odbywa się to zawsze kosztem wolności) i przyszłych korzyści materialnych i zdrowotnych, zarządcy interesu są w stanie uzyskać entuzjastyczne poparcie dla najbardziej nawet absurdalnego projektu. W kościach nowonarodzonych noworodków mają być umieszczane chipy, co wyeliminuje wszelkie przestępstwa dokonywane na dzieciach. W powieści spotykamy niezwykle sugestywny opis randki (test aplikacji Lublub), podczas której można przejrzeć dane osoby i jej rodziców, dowiedzieć się o jej przeszłości niemal wszystko, o chorobach, na jakie zapadała, co zażywała, informacje o dramatach $\mathrm{w}$ rodzinie etc.

Mae usprawiedliwia tą inwigilację, odwołując się do przesłanek zdroworozsądkowych: „Wiedza stanowi podstawowe prawo człowieka. Równy dostęp do wszystkich możliwych ludzkich doświadczeń jest podstawowym prawem czło-

\footnotetext{
33 Tamże, s. 255.

${ }^{34}$ Tamże, s. 294-295.
} 
wieka" ${ }^{35}$. Drogą do tego jest filmowanie wszystkiego, co się przeżywa i dzielenie się tym $\mathrm{w}$ sieci. Wątpiących wprowadza się w poczucie winy, odwołując się choćby do biednych niepełnosprawnych dzieci, które mogą doświadczyć ekscytujących przygód, podglądając jedynie w sieci życie innych.

W liście Mercera do Mae możemy odkryć jakże bliskie niebezpieczeństwo dotyczące każdej istoty zmuszonej do pogoni za „maszyną” (dotyczy to również pracowników naukowych poddawanych wyrafinowanym parametryzacjom stworzonym przez wielkie korporacje, nieraz w zupełnie innym celu, np. Thomson Reuters, którzy kosztem twórczości gonią za wirtualną aprobatą, uznaniem, szacunkiem, medalem i coraz mniej „ważącymi” tytułami):

„Czy zastanawiałaś się kiedyś nad tym, że nasze umysły są delikatnie skalibrowane między tym, co wiadome, a tym, co niewiadome? Że nasze dusze potrzebują tajemnic nocy i jasności dnia? Tworzycie świat bezustannego światła dziennego i myślę, że ono spali nas wszystkich żywcem. Nie będzie czasu na refleksję, na sen, na ochłonięci. Czy kiedykolwiek przyszło wam, pracownikom Circle, do głowy, że więcej nie zdołamy w niej pomieścić? (...) Nasze głowy są niewielkie, mają wielkość melona. Chcecie, żeby w tych naszych głowach zmieściło się wszystko, co kiedykolwiek widział świat? To się nie uda"36.

Wedle niektórych bardziej kulturowo zorientowanych psychiatrów ${ }^{37}$ depresja może być reakcją obronną organizmu, aczkolwiek paradoksalną, związaną z nagłym przeskokiem od cywilizacji przemysłowej do pędu cywilizacji informatycznej. Jeśli rzeczywiście taki proces ma miejsce, być może istota ludzka w ten sposób, ulegając chorobie, broni swój umysł przed spłonięciem w maniakalnym ogniu. Bóg ponowoczesności - Wielki Mózg, otoczony przez wiernych neuroproroków, sam płonąc, spala mózgi podążających za jego szaleństwem, połączonych siecią, imagopatów.

35 Tamże, s. 293.

${ }^{36}$ Tamże, s. 417.

${ }^{37} \mathrm{~W}$ Polsce zwraca uwagę na ten aspekt profesor Bohdan Wasilewski. Między innymi w referacie pt. „Depresja i tanatoza w ujęciu antropologicznym”, wygłoszonym 19 października 2014 roku na konferencji „Psychoterapia i kultura. Diagnoza cywilizacji sukcesu”. 
Mercer ucieka na północ, coraz dalej, ukrywa się w lesie. Ale prywatność staje się czymś podejrzanym, a co za tym idzie, jeszcze bardziej podejrzane jest życie poza zasięgiem sieci. Namierzony, słyszy dźwięk z drona: „Poddaj się. Bądź naszym przyjacielem

Jak Dzikus z „Nowego wspaniałego świata” zaszczuty Mercer popełnia samobójstwo, rozpędzonym samochodem rzuca się w przepaść. Od razu ma miejsce dyskusja w Circle o stworzeniu aplikacji, która uniemożliwiałaby w przyszłości popełnianie przy pomocy samochodów samobójstw. Ocena postawy Mercera przez media kontrolowane przez Korporację jest zdeformowana przy pomocy mechanizmu racjonalizacji. Ten ponowoczesny „Dzikus” zostaje określony mianem niezrównoważonego, aspołecznego. Człowieka, który mieszkał samotnie i wpadł w depresję, doprowadził się do szaleństwa i paranoi.

Sfinalizowaniem władzy medialnego imperium jest domknięcie, czyli przymus obowiązkowego konta w Circle i używanie obnażającego z wszelkiej anonimowości programu TruYou. Niby jest to pomysł pnącej się ku szczytom kariery Mae, ale czy rzeczywiście jej? „Wszyscy będą obserwowani od kołyski aż po grób, bez możliwości ucieczki” ${ }^{38}$.

W globalnej kulturze cyfrowej już truizmem stało się stwierdzenie, że możliwość kontrolowania przepływu informacji - oznacza możliwość kontroli nad wszystkim. Jeśli wszyscy będą obserwowani, wszyscy staną się obywatelami Circle - nie będzie przestępstw, morderstw, gwałtów, żadnych zaginionych osób, prześladowania dzieci. Oto cud życia przejrzystego. $Z$ drugiej strony, czyż nie jest tak, że: „Większość ludzi zamieniłaby wszystko, co wiedzą, wszystkich, których znają... zamieniliby to wszystko na świadomość, że ich widziano i zauważono, a może nawet zapamiętano. Wszyscy wiemy, że czeka nas śmierć, że świat jest zbyt duży, byśmy odgrywali w nim znaczącą rolę. Mamy więc tylko nadzieję, że nas widziano bądź słyszano, choćby przez chwilę339.

Nad tymi nowinkami wspaniałej ery cyfryzacji unosi się potwór: destruktywna konsumpcja. Psychopatyczny Stenton, jeden z mózgów korporacji, skutecznie zamieniający utopię $\mathrm{w}$ biznes, wpatruje się $\mathrm{z}$ ekstazą $\mathrm{w}$ rekina $\mathrm{z}$ głębin,

\footnotetext{
38 Tamże, s. 465.

${ }^{39}$ Tamże, s. 468.
} 
pływającego w wielkim akwarium, w bestię, która przerabia przez swą żarłoczność i błyskawiczne trawienie, wszystkie stworzenia na popiół.

Przerażony Ty, który stoi na czele buntowników i próbuje pod pseudonimem „Kalden” bezskutecznie obalić to, co sam stworzył pisze tylko coś co zapewne prawie nikt nie przeczyta, mianowicie Prawa ludzi w erze cyfryzacji: „Wszyscy musimy mieć prawo do anonimowości. Nie każdą ludzką aktywność da się zmierzyć. Bezustanna pogoń za danymi, żeby określić ilościowo wartość wszelkich poczynań, jest katastrofą dla prawdziwego zrozumienia. Granica między tym, co publiczne, a tym, co prywatne, musi pozostać nienaruszalna (...) Wszyscy musimy mieć prawo zniknąc" ${ }^{30}$.

Odwołujący się do marksizmu i psychoanalizy, współczesny brytyjski myśliciel Terry Eagleton zauważa, że w ujęciu Freuda Eros i Tanatos są blisko z sobą powiązane. Jednak prawdziwy skandal psychoanalizy polega na wprowadzeniu przez Freuda tezy, że „istoty ludzkie nieświadomie pragną własnej destrukcji” ${ }^{41}$

Istota ta, opętana przez obsesyjne pragnienia, poruszając $\mathrm{w}$ napięciu wahadłem wpada w pułapkę Tanatosa, zarówno kiedy zmierza ku tradycji i szkodliwego dla życia i zdrowia skostnienia, jak i ku chasowi maniakalno-depresyjnej (i coraz bardziej autystycznej) ponowoczesności.

Homo inhumanus oznacza po łacinie chama, człowieka bezczelnego, nie przestrzegającego podstawowych regul, grubianina. Peter Sloterdijk ${ }^{42}$ tym terminem określił człowieka pozbawionego hamulców, zauważając, że w kulturach wysoko rozwiniętych wychowanie i edukacja podlegają dwojakim wpływom: hamującym i pozbawiającym hamulców. A człowiek pozbawiony hamulców był dla starożytnych Greków kimś niebezpiecznym, ściągającym nieszczęście nie tylko na siebie samego, ale i na swą rodzinę i przyszłych potomków. Był tym, który przekraczał „hybris”, czyli padał ofiarą autodestrukcyjnej siły, popychającej ku przekraczaniu własnych możliwości i wbijającej w megalomańską wiarę

\footnotetext{
${ }^{40}$ Tamże, s. 468.

${ }^{41}$ T. Eagleton, Zto, przeł. B. Baran, Warszawa 2012, s. 104.

${ }^{42}$ Por. P. Sloterdijk Reguty dla ludzkiego zwierzyńca. Odpowiedź na Heideggera list o humanizmie, przeł. A. Żychliński, „Przegląd Kulturoznawczy” nr 4/2008, s. 40-62.
} 
w siebie. Parafrazując Sloterdijka, można rzec, że tak jak książka w Starożytnym Rzymie przegrała $\mathrm{z}$ amfiteatrem; w nowoczesności szkoła $\mathrm{z}$ telewizją i kinem pełnym przemocy, tak w ponowoczesności tzw. kultura wyższa roztapia się w infantylno-coachingowo- marketingowej światłości kultury cyfrowej.

Kultura cyfrowa zmienia nasze doświadczenie czasu, nie jest to już ani czas linearny, ani cykliczny, lecz punktowany ${ }^{43}$. Każdy osiaggany punkt staje się celem, mamy tu do czynienia z imitacją mistycznego doświadczenia chwili teraźniejszej. A paradoks polega na tym, że jest to doświadczenie bez doświadczenia. Życie czasem punktowanym jest życiem bez nudy i oczekiwania, bez drogi. Stąd zmianie ulega nasze doświadczenie przestrzeni. Przede wszystkim zanika różnica pomiędzy ruchem a byciem poruszanym, pomiędzy tym, co za oknem, a tym, co na ekranie smartfonów i tabletów. Przyspieszenie podróży i „skokowe” (od punktu do punktu) doświadczanie czasu likwiduje wszelkie niespodzianki możliwość głębszych przeżyć estetycznych czy mistycznych. $Z$ drugiej strony zdesakralizowana, anestetyczna przestrzeń świata na zewnątrz odpycha umysł w kierunku wirtualnemu światu niby nieograniczonych możliwości. Ale, co jest istotne dla pracowników naukowych, którzy być może są już ostatnimi humanistami, kultura cyfrowa zubaża doświadczenie lektury. W ogromnej ilości plików często poszukujemy jednego słowa i czytamy jedno, dwa zdania wybrane przez program, rozbudowujemy imponujące przypisy, jeszcze bardziej imponującą bibliografię i w efekcie pozostaje wielkie otępienie i nadymanie się urojoną mądrością. A przecież zdarza się, że otwieramy tekst (niby już znany) na innej, niepotrzebnej stronie na której znajdujemy to coś, które staje się nawet pchnięciem ku mistycznemu przeżyciu, a częściej może się stać doświadczeniem, które zmieni naszą perspektywę postrzegania siebie, kultury i świata naturalnego ${ }^{44}$.

To że częścią naszego życia stało się funkcjonowanie w świecie wirtualnym jest czymś tak oczywistym, że aż banalnym. Ale w konsekwencji doświadczamy tego, że przedmioty, wydawałoby się materialne, dematerializują się. Stawiamy oceny w wirtualnych indeksach, odbieramy wirtualne dyplomy, nagrody, pienią-

${ }^{43}$ Por. Z. Bauman, Konsumowanie życia, przeł. M. Wyrwas-Wiśniewska, Wydawnicto UJ, Kraków 2009, s. 40.

${ }^{44}$ Por. T. Olchanowski, Kultura manii, Eneteia. Wydawnictwo Szkolenia, Warszawa 2016. 
dze w formie wypłaty, którymi później „wirtualnie” płacimy. A jeśli jesteśmy graczami, możemy oskarżać (nawet przed sądem) innych graczy o kradzież wirtualnych gadżetów. A przyczynowość? Współzależność zjawisk? Jest niemal identyczna jak w świecie magii i marzeń sennych, gdzie obowiązują prawa podobieństwa i styczności ${ }^{45}$. Prawo podobieństwa wskazuje na mylenie podobieństwa $\mathrm{z}$ tożsamością, a to znaczy, że pomiędzy różnymi rzeczami wszystkie przedmioty o podobnych cechach wydają się być identyczne i dlatego mogą być wymienialne (Freud nazwałby te zjawisko przemieszczeniem). Prawo zarażenia z kolei dotyczy tego, że z tożsamością mylone są sąsiedztwo, bliskość, a więc jednostki, które miały kiedyś ze sobą kontakt, postrzegane są już jako pozostające w związku bądź wzajemnie uzależnione. Oznacza to również, że każda część całości zawiera jej esencję (niemal analogiczny mechanizm Freud określił mianem zagęszczenia). ${ }^{46}$ Inaczej mówiąc, prawo podobieństwa mówi nam, że obraz jest tym w stosunku do rzeczy, czym część w stosunku do całości, oraz że upodobnienie powoduje skutki w określonym kierunku. W świecie magii prawo to było stosowane w obrzędach uroku (nie była potrzebna styczność z obiektem, wystarczyła jego podobizna bądź symboliczne przedstawienie). Dwie podstawowe formuly tego prawa to: podobne wywołuje podobne; podobne działa na podobne, a zwłaszcza je leczy. Co się tyczy prawa zarażenia, przekazuje ono nam, że osobowość danej istoty jest niepodzielna i mieści się w każdej części, dotyczy to także rzeczy. Na przykład wierzono niegdyś, że zęby, pot, paznokcie, włosy przedstawiają całą istotę, że w każdym płomieniu zawiera się ogień, w każdej kości śmierć. Styczność rozciągała się w przestrzeń, poza ciało, to znaczy, że ubrania, ślady, tóżko przypisywano poszczególnym częściom ciała. Mylono z tożsamością związek między człowiekiem a rodziną, domem, jego zwierzętami, a także dostrzegano tajemnicze powiązania pomiędzy mordercą a ofiarą (wierzono, że trup zaczyna krwawić, gdy zbliży się doń morderca).

${ }^{45}$ Por. J. Frazer, Ztota gataź, przeł. H. Krzeczkowski, PIW, Warszawa 1962.

${ }^{46}$ Por. K. Wilber, Eksplozja świadomości, przeł. K. Przechta, E. Kluz, Kraków 1997, s. 89. Także por. T. Olchanowski, Psychologia pychy, Eneteia. Wydawnictwo Psychologii i Kultury, Warszawa 2003, s. 172-173. 
M. Mauss wyróżnił trzecie prawo magii (powiązane z prawem podobieństwa), mianowicie prawo przeciwieństwa ${ }^{47}$. Skoro podobne uzdrawia podobne, to znaczy, że wywołuje przeciwne. Wyrażając w inny sposób, podobne usuwa podobne, aby pobudzić przeciwne. Możemy przerwać deszcz, przywołując jego przeciwieństwo - słońce. Prawo przeciwieństwa odkrywa nam, że skojarzenia mogą pojawiać się również przez kontrast, np. biały - czarny, powodzenie pech, zimno - ciepło, woda - ogieñ, wolność - przymus, sterylizacja - płodność etc.

Czyż ten świat nie jest nam znajomy? Już nie tylko wiąże się z wirtualną rzeczywistością imagopatów, ale wciąż przenika do świata polityki, jak również zarządzania nauką (parametryzacja i magiczna wiara, że geniusz można zmierzyć ilością punktów, a w każdym punkcie mieści się istota geniuszu). Jest paradoksem, że w czasach rozkwitu neuronauk i redukcji istoty ludzkiej do przestrzeni między uszami (fizycznego mózgu) oparta na magii i emocjach rzeczywistość mityczna owładnęła umysły najbardziej racjonalnych zarządców interesu i neuroentuzjastów. Być może, kiedy myślenie racjonalistyczne wznosi się na racjonalne wyżyny, osiąga taki punkt, od którego, parafrazując Heraklita: „Droga w górę jest drogą w dół”.

Kulturze cyfrowa zapewne w znacznym stopniu przyczynia się do erupcji myślenia mitycznego, $\mathrm{z}$ jednej strony $\mathrm{w}$ formach najbardziej irracjonalnych i prymitywnych, z drugiej zaś, erupcja ta odbywa się w dwóch wzajemnie przenikających się przestrzeniach, istniejących poza światem jawy i snu: realnej i wirtualnej. A co umożliwiło erupcję? Myślenie racjonalne, które okazało się jedynie, czy aż, irracjonalnym mitem nauki.

${ }^{47}$ Zob. M. Mauss, Socjologia i antropologia, przeł. M. Król, K. Pomian, J. Szacki, PWN, Warszawa 1973. 


\title{
POSTMODERN WONDERFUL WORLD OF IMAGOPATHS
}

\author{
Summary
}

This article focuses on the phenomenon of digital culture. Through the prism of Jungian psychology, it looks at the madness of imagopathy. The virtual world transcends the boundaries between wakefulness and dream, between rational and mythical thought. This is the world of samsara, governed by the law of enantiodromia. Freud believed that people unconsciously want their own destruction. The final destructiveness rational order is based on the famous antiutopias, „Brave New World” by Aldous Huxley and „The Circle” by Dave Eggers. Conclusion: Everything is a myth. Rational thought is an illusion.

Key words: imagopathy, logorea, psychic reality, enantiodromia, anti-utopias, mythical thought, the myth of science, digital culture

Słowa kluczowe: imagopatia, logorea, rzeczywistość psychiczna, enancjodormia, antyutopie, myśl mityczna, mit nauki, kultura cyfrowa

\section{Biliografia}

Ajschylos, Sofokles, Eurypides. Antologia tragedii greckiej, przeł. S. Srebrny, K. Morawski, J. Łanowski, wybór i opracowanie S. Stabryła, Wydawnictwo Literackie, Kraków 1989.

Bal-Nowak M., Mit jako forma symboliczna w ujęciu Ernsta Cassirera, Wydawnicwo Nomos, Kraków 1996.

Bauman Z., Konsumowanie życia, przeł. M. Wyrwas-Wiśniewska. Wydawnicto UJ, Kraków 2009. Burszta W.J., Preteksty, Wydawnictwo Naukowe Katedra, Gdańsk 2015.

Campbell J., Potega mitu, przeł. I. Kania, Sigma, Kraków 1994.

Cassirer E., Pojęcie formy symbolicznej w budowie nauk humanistycznych, [w:] Symbol i jezzyk, przeł. i red. B. Andrzejewski, Wydawnictwo Naukowe IF UAM, Poznań 1995.

Cassirer, E., Esej o cztowieku, przeł. A. Staniewska, Czytelnik, Warszawa 1977.

Cassirer, E., Mit państwa, przeł. A. Staniewska, Wydawnictwo Instytutu Filozofii i Socjologii PAN, Warszawa 2006.

Eagleton T., Zto, przeł. B. Baran, Czytelnik, Warszawa 2012.

Eggers D., Krag, przeł. M. Fedyszak, Wydawnictwo Sonia Draga, Katowice 2015.

Fháner S., Stownik psychoanalizy, przeł. J. Kubitsky, GWP, Gdańsk 1996.

Frazer J., Ztota gatą, przeł. H. Krzeczkowski, PIW, Warszawa 1962.

Huxley A., Nowy wspaniaty świat, przeł. B. Baran, Wydawnictwo Literackie, Kraków 1988.

Jaeger W., Teologia wczesnych filozofów greckich, przeł. J. Wocial, Homini, Kraków 2007. 
Jung C.G., Psychologia kundalini-jogi. Wedtug notatek z seminariów 1932 opracowat Sonu Shamdasani, przeł. R. Reszke, KR, Warszawa 2003.

Jung C.G., Psychologia a religia, przeł. J. Prokopiuk, Wrota, Warszawa 1997.

Jung C.G., Typy psychologiczne, tłum. R. Reszke, Warszawa 1997.

Jung C.G., Wspomnienia, sny, myśli. Spisane i podane do druku przez Aniele Jaffé, przeł. R. Reszke i L. Kolankiewicz, Warszawa 1997.

Kania I., Muttavali. Wypisy z ksiag starobuddyjskich, Aletheia, Warszawa 2007.

Krishnamurti J., Catkowicie inny sposób życia, przeł. R. Kubik, KOS, Katowice 2008.

Kundera M., Zachód porwany albo tragedia Europy Środkowej, „Zeszyty Literackie” nr 5/1984.

Mauss M., Socjologia i antropologia, przeł. M. Król, K. Pomian, J. Szacki, PWN, Warszawa 1973.

Nietzsche F., Ecce homo, przeł. L. Staff, Warszawa, Mortkowicz, Warszawa 1912.

Nietzsche F., Zmierzch bożyszcz, czyli jak filozofuje się mtotem, przeł. S. Wyrzykowski, Warszawa 1910.

Olchanowski T., Kultura manii, Eneteia. Wydawnictwo Szkolenia, Warszawa 2016.

Olchanowski T., Psychologia pychy, Eneteia. Wydawnictwo Psychologii i Kultury, Warszawa 2003.

Olchanowski T., Wola i opętanie. Enancjodromia i rzeczywistośc, wydanie II (poszerzone), Eneteia. Wydawnictwo Psychologii i Kultury, Warszawa 2010.

Raube S., Powracający mit: idea regresu w filozofii kultury Ernsta Cassirera, „Kultura i wartości”, 2(10)/2014.

Sloterdijk P. Reguty dla ludzkiego zwierzyñca. Odpowiedź na Heideggera list o humanizmie, przet. A. Żychliński, „Przegląd Kulturoznawczy” nr 4/2008.

Wilber K., Eksplozja świadomości, przeł. K. Przechta, E. Kluz, Abraxas, Kraków 1997.

dr hab. Tomasz Olchanowski

Uniwersytet w Białymstoku, Wydział Pedagogiki i Psychologii, Katedra Teorii Wychowania i Antropologii Pedagogicznej 